\title{
THE IMPACT OF MANAGEMENT SYSTEMS ON THE ACTIVITIES OF ENTERPRISES IN THE AREA OF PEST CONTROL
}

\author{
Justyna GÓRNA \\ Poznań University of Economics and Business; justyna.gorna @ ue.poznan.pl, ORCID: 0000-0002-2763-5810
}

Purpose: Many factors influence the safety of food, feed, cosmetics or packaging for these products. These include legal requirements, proper people behaviour, management systems and the organisational culture used in enterprises, as well as activities related to the prevention/minimisation/elimination of microbiological, chemical and physical hazards. A very important link in ensuring the safety of manufactured products are, among others, suppliers, including service providers in the area of pest control. Providers of these services must adapt to the requirements of the enterprise to which they provide services. In turn, the requirements of the enterprise are dictated by the requirements of the management standard for compliance with which the enterprise maintains the certificate; therefore, the requirements of individual management standards should be known to pest control companies to avoid the risk of noncompliance. The main purpose of the article was to present the importance of knowing the requirements of the food safety management system by the service provider in the area of pest control.

Design/methodology/approach: An analysis of the requirements of selected food safety management standards in the pest control area was carried out.

Findings: The analysis showed similarities in requirements in the area of pest control of selected food safety management standards.

Practical implications: Based on the analysis, recommendations for good practices in the field of protection against pests were formulated. Good practice guidelines should be used by service providers in the pest control area.

Originality/value: The article contains important guidelines on good practices in the field of protection against pests.

Keywords: pest control, management system, food safety.

\section{Introduction}

Many factors affect the safety of food, feed, cosmetics and packaging for these products. These include legal requirements, proper people behaviour, management systems and the organisational culture used in enterprises, as well as activities related to the 
prevention/minimisation/elimination of microbiological, chemical and physical hazards. Legal requirements set out rules for monitoring the use of raw materials and rules for handling them. This is primarily aimed at preventing, eliminating or minimising the occurrence of microbiological, chemical and physical hazards. This is the extent to which the company pursues legal requirements and ensures proper handling of raw materials, finished products or the manufacturing process will probably depend on the management system adopted in the organisation and its culture (Manning, and Baines, 2004; Kołożyn-Krajewska, and Sikora, 2010; Górna, 2018). A very important link in ensuring the safety of manufactured products are, among others, suppliers, including service and product suppliers. The role of DDD service providers includes providing services mainly to food, feed, packaging or cosmetics processing companies. The industries listed are interrelated, and the activities of each industry are governed by mandatory requirements (legal requirements), though they are also voluntary (management standards).

\section{Management standards}

Enterprises can operate within the framework of standardized management systems, which are based on one or more standards of quality and safety management (Table 1).

In the food industry, enterprises can implement standards such as (Trafiałek, and Kolanowski, 2017):

- ISO 22000: 2018 Food safety managements systems - Requirements for any organisation in the food chain,

- FSSC 22000 Food Safety System Certification,

- BRC Global Standard Food Safety,

- IFS International Food Standard,

- GLOBALG.AP The Worldwide Standard for Good Agricultural Practices,

- QS Quality scheme for safe food.

In the industry of manufacturing materials and packaging products, the following are implemented:

- BRC Packaging and Packaging Materials,

- IFS PACsecure,

- ISO 22000: 2018 Food safety managements systems - Requirements for any organization in the food chain.

In the manufacture of cosmetic products, the following standards shall be implemented:

- ISO 22716 Good Practices for Cosmetics Production (GMP),

- BRC CP Global Standard Consumer Products,

- IFS HPC Household and Personal Care Standard. 
Table 1.

Characteristics of selected standards

\begin{tabular}{|c|c|c|c|c|}
\hline & ISO 22000 & FSSC 22000 & IFS & BRC \\
\hline Type & $\begin{array}{c}\text { International } \\
\text { Standard }\end{array}$ & Private Standard & Private Standard & Private Standard \\
\hline $\begin{array}{l}\text { Distributor (owner } \\
\text { of the standard ) }\end{array}$ & $\begin{array}{c}\text { ISO } \\
\text { (International } \\
\text { Standard } \\
\text { Organization) }\end{array}$ & $\begin{array}{l}\text { The Foundation for } \\
\text { Food Safety } \\
\text { Certification } \\
\text { (Netherlands ) }\end{array}$ & $\begin{array}{c}\text { HDE - } \\
\text { Hauptverband des } \\
\text { Deutschen } \\
\text { Einzelhandels } \\
\text { (Germany) } \\
\text { FCD - Federation } \\
\text { des enterprises du } \\
\text { Commerce et de la } \\
\text { Distribution } \\
\text { (France) } \\
\end{array}$ & $\begin{array}{c}\text { BRC - British Retail } \\
\text { Consortium (United } \\
\text { Kingdom) }\end{array}$ \\
\hline Category & System Certification & $\begin{array}{c}\text { certification } \\
\text { system }\end{array}$ & $\begin{array}{c}\text { Product } \\
\text { Certification }\end{array}$ & $\begin{array}{c}\text { Product } \\
\text { Certification }\end{array}$ \\
\hline Recognition & International & $\begin{array}{l}\text { Recognised standard } \\
\text { by GFSI (Global } \\
\text { Food Safety } \\
\text { Initiative) - can be } \\
\text { recognised } \\
\text { interchangeably } \\
\text { with BRC or IFS } \\
\end{array}$ & $\begin{array}{l}\text { Traders: continental } \\
\text { part of Europe }\end{array}$ & $\begin{array}{c}\text { Traders: UK, } \\
\text { Belgium, Germany, } \\
\text { Scandinavia }\end{array}$ \\
\hline End result & certificate & $\begin{array}{c}\text { Certificate } \\
\text { The obligation of an } \\
\text { unannounced audit }\end{array}$ & $\begin{array}{c}\% \\
\text { Points scored/total }\end{array}$ & $\begin{array}{c}\text { Level } \\
\text { (depends on the } \\
\text { number and nature } \\
\text { of non-compliance) }\end{array}$ \\
\hline Who is required & voluntary & $\begin{array}{c}\text { Customer } \\
\text { requirement }\end{array}$ & $\begin{array}{c}\text { Customer } \\
\text { requirement }\end{array}$ & $\begin{array}{c}\text { Customer } \\
\text { requirement }\end{array}$ \\
\hline Certificate validity & 3 years & 3 years & 1 year & 1 year \\
\hline
\end{tabular}

Source: own study based on (IFS, BRC, FSSC 22000, ISO 22000).

In the manufacture of feed, enterprises have at their disposal such standards as:

- QS Quality scheme for safe food,

- GMP + International,

- ISO 22000: 2018 Food safety managements systems - Requirements for any organisation in the food chain.

Voluntary certification according to various standards is often necessary if an organisation wants to cooperate with various commercial networks. You do not have to be a supplier of the final product, because e.g. a supplier of raw materials or semi-finished products may also be obliged by your client to certify compliance with the indicated standard. All of the above standards regulate, among others, rules for purchasing raw materials and services. Entities supplying raw materials or services are subject to qualification and assessment. The assessment of such suppliers must be carried out at least once a year. The evaluation criteria include quality of raw materials/ services provided, handling of comments/ complaints, price of products/ services offered, timely delivery of orders.

The service provider in the pest control area undoubtedly has a great impact on ensuring the security of processes carried out in the customer's enterprise. Its reliability, meticulousness and adaptation to the requirements of the enterprise's standard will depend on the result with which 
a given company obtains a certificate during an external audit. The results of such an audit often affect the possibility of delivering products to a given customer. Therefore, companies attach great importance to the best preparation for such an audit. Activities in the area of pest control in the requirements of most standards relate to:

- pest risk analysis,

- pest presence monitoring,

- principles of documentation,

- effective protection of the plant against access by pests,

- station locations/ traps/ insecticide lamps,

- management of pest infestations,

- an annual assessment of a functioning pest management system by an independent expert.

Each enterprise in the pest control area providing services to enterprises in the food, packaging, cosmetics or feed industry should have knowledge of compliance with which standards the management systems operate in the enterprises of their clients. One should then become familiar with the requirements of a given standard and review the developed pest control programme in terms of meeting these requirements.

The development of quality and safety management systems, as well as the current global situation, forces enterprises to build a system not only providing protection against incidental product contamination, but also against intentional contamination. Intentional contamination of products can be initiated by various groups, both direct entities, e.g. an angry employee, or indirect entities, i.e. suppliers of raw materials/services and subcontractors (Adams, and Marsh, 2014; PAS 96: 2014; Wiśniewska, 2016). Therefore, representatives of pest control companies must also take into account other restrictions applied to them when they enter the premises of their client's company, e.g. with:

- lack of free access to all areas of the enterprise,

- the need to declare consent to proceed in accordance with the requirements of the enterprise,

- the presence of an accompanying person from the undertaking during the implementation of the service,

- the need to inform the customer in advance about a change in the employee providing the pest control service.

Generally, the pest control company that wants to provide services for companies from the industries analysed in this article must have competent employees and respond quickly to customer needs. It should be borne in mind that standards change every three years on average, and it is then necessary to ensure that these changes also apply to the pest control area. 


\section{Requirements of selected standards in the area of pest control}

As required by the BRC standard, the plant must have an effective pest control programme in place to eliminate the risk of contaminating raw materials, packaging and finished products. The standard requires the company to commission pest management to a qualified entity or to rely on qualified employees. For the latter option, pest management staff must meet legal training requirements. If the establishment uses the services of an external company, then the scope of work must be precisely defined - clearly defined responsibilities of the plant management and service contractor. Most often, the scope of services is clarified in the pest control contract and programme. As part of the documentation and records maintained, you must ensure:

- a risk assessment, which must be reviewed whenever changes are made to the buildings or the production process and may have an impact on the pest control programme, or when a serious pest problem occurs,

- current plan of the entire plant, indicating the places where the pest control devices are located,

- identification of deratisation stations and/or monitoring equipment in the establishment,

- detailed information on the pest control measures used, including instructions on their proper use and emergency response,

- records of all observed pest activity cases,

- details of measures taken to control pests.

The standard allows for the possibility of keeping records on paper or in an electronic system (e.g. in the online reporting system). Deratisation stations or other devices used to monitor or control rodents must be arranged and maintained so that there is no risk of product contamination. If a deratisation station is lost, this fact should be recorded, and the reason for its loss should be determined. Toxic rodent baits may not be used in production or storage areas in which the open product is located, except for pest invasion activities. Toxic indoor baits can then be introduced for indoor use, but the entire process must be meticulously supervised and monitored. Insect killing devices, pheromone traps and / or other insect monitoring devices must be operational and properly positioned. If there is a risk of insects being ejected from the insecticide equipment and thus contaminating the product, other systems and equipment must be used. In the presence of pests or traces of their activity, it is necessary to take immediate action to identify endangered products and to minimise the risk of product contamination. All potentially contaminated products must undergo a non-compliant product handling procedure.

All inspections must be recorded and contain information on any pest protection introduced, hygiene recommendations or actions to be taken to prevent pests. 
The company is responsible for ensuring that all relevant recommendations made by the service contractor or specialists employed at the plant are implemented in a timely manner. In order to verify the effectiveness of pest control measures applied in the plant, a thorough and documented review of pest control measures should be carried out. This review (audit) must be carried out by an expert with a risk-based frequency, but at least once a year. The review should:

- include thorough site inspection for pests,

- provide an overview of the pest management measures used and any recommendations for changes.

The results of pest control inspections must be regularly evaluated and analysed for trends, at least once a year, or always when pest infestation occurs. The analysis must include monitoring results from traps and monitoring devices to identify problem areas. First of all, the analysis must form the basis for improving pest protection procedures. The standard also requires employees to be able to recognise traces of pest activity and know that they should inform supervisors about such situations. To this end, training sessions are carried out at plants, which are most often outsourced to a company providing pest control services (BRC Global Standard Food Safety, issue 8, 2018).

The IFS standard requires the production company to have a pest control system that complies with legal requirements, and when establishing such a system, it must take into account at least: the environment of the plant (potential pests), the plan of the plant with the location of the traps (map of the traps), marking the traps on site, those responsible (from personnel/outsiders), products/measures used and instructions for their use and safety, as well as the frequency of inspections. The pest control system must be based on an analysis of the hazards and an assessment of the risks associated with them. The company should have qualified and trained personnel and/or hire a competent external company. When hiring an external company, all actions necessary to take up the plant should be recorded in the contract. Pest control inspections and activities resulting from these inspections must be documented, and the implementation of activities should be monitored and recorded. Baits, rodent traps and insect traps must be in the correct amount and positioned appropriately. They must be made and arranged so as not to present a risk of contamination. The effectiveness of pest control should be monitored by means of regular trend analyses (International Food Standard, issue 6, 2012). 


\section{Good practices in the field of pest management in terms of meeting the requirements of the standards}

The requirements of the standards are more or less detailed; however, every company operating on the market of pest control services should develop its code of good practices. Meeting the following requirements in the scope of the pest control programme and information saved as a result of inspections (monitoring reports) will satisfy the majority of enterprises using the services of companies in the pest control area, regardless of the standard in a given enterprise (Table 2).

Table 2.

Good practices in the field of protection against pests

\begin{tabular}{|c|c|}
\hline Pest Control Programme & Reports from the pest control programme \\
\hline - $\quad$ pest control programme supplier data & - $\quad$ all observations of pests and their activity \\
\hline $\begin{array}{l}\text { - pest management programme supplier training } \\
\text { certificates }\end{array}$ & $\begin{array}{l}\text { plant recommendations for actions to be taken, } \\
\text { including hygiene and safety, as well as any } \\
\text { overdue recommendations from previous controls }\end{array}$ \\
\hline $\begin{array}{l}\text { - frequency and type of control (based on } \\
\text { documented risk assessment) }\end{array}$ & $\begin{array}{l}\text { information on the chemicals used (type, amount } \\
\text { and place) }\end{array}$ \\
\hline $\begin{array}{l}\text { establishment plan identifying the programme } \\
\text { area and pest monitoring points (e.g. toxic/non- } \\
\text { toxic baits) }\end{array}$ & - $\quad$ reports on access problems and lost baits \\
\hline $\begin{array}{l}\text { - an indication of the persons responsible at the } \\
\text { plant for supervision over DDD activities }\end{array}$ & - $\quad$ signature of designated manager or deputy \\
\hline - $\quad$ pests covered by the programme & - $\quad$ updated trend analysis \\
\hline $\begin{array}{l}\text { - pest control methods and procedures and devices } \\
\text { used }\end{array}$ & \\
\hline - the frequency of changes in fluorescent lamps & \\
\hline $\begin{array}{l}\text { procedures for verifying checks after pest } \\
\text { infestation }\end{array}$ & \\
\hline - $\quad$ safety data sheets for all chemicals used & \\
\hline $\begin{array}{l}\text { - contact details of persons to be called in case of } \\
\text { an emergency }\end{array}$ & \\
\hline
\end{tabular}

Plants commissioning pest control companies to carry out pest control activities have obligations arising from the requirements of standards, as well as good practice. These activities include supervising the pest control company (e.g. using markers to determine whether the pest control company performs the service reliably) and verifying the effectiveness of pest control's operations through, among others carrying out audits. The following are non-conformities most frequently occurring in the area of pest control, which were found as part of audits carried out by the author of this study:

- not including all pests in the control programme, e.g. insects, warehouse pests, wild animals, pets (cats, dogs), birds,

- differences between the plan for the arrangement of deratisation stations and reality (numerical/location discrepancy/no numbering on the device), 
- no safety data sheets (this happens when funds change and pest control does not update the documentation),

- outdated pest management programme - once a year it should be reviewed and approved by date and signature,

- unconfirmed floor stations,

- dirty, uncleaned insecticide lamps,

- blocked deratisation stations,

- no traps for running insects, e.g. in staff canteens, cloakrooms,

- lack of compliance of the scope of services defined in the contract with the pest control company in comparison with the pest management programme or vice versa - a wider scope in the contract and lack of reflection in activities,

- deratisation stations not permanently closed,

- unsealed/unsecured buildings against access by pests,

- about open steel door gate/door,

- no actions/procedures in the field of pest movement trend analysis. There is no specific value threshold of initiating a corrective action,

- no evidence of replacement of fluorescent lamps in insecticide lamps,

- failure to include newly created facilities on the company's premises, e.g. a tent warehouse, into the pest management programme.

Improvement activities are an indispensable element of management systems, which is why enterprises in the area of pest control must take into account that the requirements of standards will evolve. Each standard is updated at least for a period of 3 to 5 years. Requirements are updated, among others, based on new risks which will be observed on the market and the results of certification audits.

\section{Summary}

Providing for the safety of manufactured products for limiting the risks of contamination by chemical, physical and biological hazards is undoubtedly one of the most important areas in need of efficient regulation in enterprises. First of all, enterprises have to meet legal requirements for the production of safe products, and in addition, through the desire to maintain their market leadership, they often decide to implement a management system based on available standards. The key role in requirements of product quality and safety management standards is played by the need to ensure effective pest control. Enterprises operating in this segment of services must strive to know the requirements of these standards and the organisation of work, so as not to create situations resulting in nonconformity. 


\section{References}

1. Adams, A., Marsh, K. (2014). Assessing Threats \& Vulnerabilities for Food Defence. Techni-K Consulting Ltd. \& Adele Adams Associates Ltd.

2. BRC Global Standard Food Safety (2018), 8.

3. Górna, J. (2018). Społeczna odpowiedzialność przedsiębiorstw w zakresie przestrzegania zasad higieny na etapie produkcji podstawowej. Zagadnienia Doradztwa Rolniczego. 1.

4. International Food Standard (2012), 6. Berlin: HDE Trade Services.

5. ISO 22000:2018. Food safety managements systems - Requirements for any organization in the food chain.

6. Kołożyn-Krajewska, D., Sikora, T. (2010). Zarzadzanie bezpieczeństwem żywności. Teoria i praktyka. Warszawa: Wydawnictwo C.H. Beck.

7. Manning, L., Baines, R.N. (2004). Effective management of food safety and quality. British Food Journal, 106, 8.

8. PAS 96:2014, Guide to protecting and defending food and drink from deliberate attack. The British Standards Institution.

9. Trafiałek, J., Kolanowski, W. (2017). Implementation and functioning of HACCP principles in certified and non -certified food businesses. A preliminary study. British Food Journal, 119,.4.

10. Wiśniewska, M. Z. (2016). Systemowe zarządzanie obrona żywności przed terroryzmem. Wydawnictwo Uniwersytetu Gdańskiego.

11. www.fssc22000.com, 22.05.2019. 